\title{
Spatial analysis of COVID-19 spread in Europe using "center of gravity" concept
}

\author{
Yavorska O. ${ }^{1}$, Bun R. ${ }^{1,2}$ \\ ${ }^{1}$ Lviv Polytechnic National University, \\ 12 S. Bandera Str., 79013, Lviv, Ukraine \\ ${ }^{2}$ WSB University, Dąbrowa Górnicza, Poland
}

(Received 28 August 2021; Accepted 4 February 2022)

\begin{abstract}
The COVID-19 global pandemic has affected all countries and become a real challenge for humanity. Scientists are intensively studying the specifics of the disease caused by this virus and the impact of restrictive measures on the economy, environment and other aspects of life. We present an approach to spatial modeling and analysis of the COVID19 spreading process using the concept of the "center of gravity". Based on weekly data on this disease in all European countries, the trajectories of the center of gravity of new cases and deaths during the pandemic have been calculated. These two trajectories reflect the dominant role of certain countries or regions of Europe during different stages of the pandemic. It is shown that the amplitude of the trajectory of the center of gravity in the longitudinal direction was quite high (about $1,500 \mathrm{~km}$ ) in comparison with the amplitude of the trajectory in the latitudinal direction $(500 \mathrm{~km})$. Using an approximation of the weekly data, the delays between the peaks of new cases and mortality for different countries were calculated, as well as the delays in comparison with the countries that first reached the peaks of morbidity and mortality. The trajectories of the center of gravity are also calculated for the regions of Ukraine as an example of analysis at the national scale. These results provide an opportunity to understand the spatial specifics of the spread of COVID-19 on the European continent and the roles of separate countries in these complex processes.
\end{abstract}

Keywords: spatial modeling, COVID-19 spread, center of gravity, trajectory of the center of gravity, geoinformation approach.

2010 MSC: 91B76; 65G99

DOI: $10.23939 / \mathrm{mmc} 2022.01 .130$

\section{Introduction}

Over the past two years, the global pandemic caused by COVID-19 coronavirus disease has affected all countries and has become a real challenge for humanity [1]. Daily data on new cases for all countries and regions [2], especially sad data on fatal cases, were striking in their brutality and prompted scientists to analyze all aspects of this global problem intensively. Significant efforts are being made to analyze the spread of the disease and predict the short-term consequences of various restrictive measures on both the national and regional scales.

The means for the statistical prediction of the turning point (the time that the daily new cases peak), the duration (the period that the outbreak lasts), and the attack rate (the percentage of the total population that will be infected over the course of the outbreak) for six developed countries were proposed in [3]. Zivkovic et al. [4] improved time-series prediction algorithms based on hybrids between machine learning and nature-inspired algorithms. Kim \& Kwon [5] proposed rules for selecting appropriate prediction algorithms and data imbalance resolution methods according to the characteristics of the datasets available for each country or region, and they predict the COVID-19 spread based on these algorithms. Vyklyuk et al. [6] created an approach to the modeling and analysis of different scenarios for the spread of COVID-19 by using modified multi-agent systems. Tuli et al. [7] used a mathematical model, machine learning and cloud computing to track the disease, predict the 
growth of the epidemic and design strategies and policies to manage its spread. Yakovyna et al. [8] proposed a neural network approach to short-term prediction based on administrative measures. Basu \& Campbell [9] proposed using the so-called "long short-term memory" to provide predictions and a comparison of mitigation measures in various counties in the US; this can be of help for countries and counties deciding on mitigation and reopening strategies.

COVID-19 has an impact on all spheres of society, including the economy and the environment, so the study of these impacts is another challenge for scientists [10]; the decline in economic activity has led the economies of many countries to the recession, which has not been observed since World War II. On the other hand, this has led to improved air quality due to reduced industrial activity and reduced human mobility. In addition, humanity has already lived through all of the year 2020 in a pandemic, so the collected data make it possible to compare 2020 with previous non-pandemic years. In particular, Kim et al. [11] created an epidemic disease spread model and economic situation prediction model that are based on "long short-term memory" Morgan et al. [12] analyzed the effects of COVID-19 on global economic output and sustainability. Kano et al. [13] proposed an agent-based model of the interrelation between the COVID-19 outbreak and economic activities, and the impacts of the pandemic on energy demand [14] and natural gas consumption [15] were analyzed. Werth et al. [16] studied the impact of governmental restrictions on the electrical load, generation and transmission in 16 European countries, which demonstrated the reduction of electricity generation from nuclear and fossil coal and gas sources, while the generation of renewable energy increased in most countries.

It is extremely important and interesting to study the impact of the pandemic on the environment using satellite monitoring. In particular, Straka et al. [17] examined the economic and environmental impacts of COVID-19 and lockdowns using daily Earth observation data, including day/night bands from the National Oceanic and Atmospheric Administration Suomi-NPP and $\mathrm{NO}_{2}$ measurements from the TROPOspheric Monitoring Instrument (TROPOMI), as well as using the monthly averaged cell phone data as an indicator of mobility. The high spatial resolution observations of multiple trace gases from Sentinel-5P/TROPOMI were also used to estimate the air quality impacts of COVID-19 lockdown measures [18]. The monthly Suomi National Polar-orbiting (NPP) Visible Infrared Imaging Radiometer Suite (VIIRS) day/night band composites demonstrated a decrease in light intensity caused by the lockdown enforced by the government of India in response to the COVID-19 pandemic [19]. Yusup et al. [20] studied the carbon dioxide emissions from electricity production during lockdowns; Le Quéré et al. [21] showed a temporary reduction in daily global $\mathrm{CO}_{2}$ emissions during the COVID-19 forced confinement. Liu et al. [22-25] proposed a near-real-time daily dataset of global $\mathrm{CO}_{2}$ emissions from fossil fuel; Zeng et al. [26] studied the global to local impacts on atmospheric $\mathrm{CO}_{2}$ of COVID-19 lockdowns. Weir et al. [27] analyzed the regional impacts of COVID-19 on carbon dioxide detected worldwide from space. Wang et al. [28] showed that the transportation of $\mathrm{CO}_{2}$ emissions stayed high despite COVID outbreaks; the recent impact of COVID-19 on carbon emissions in China was studied using domestic economic data in [29]. Laughner et al. [30] showed that there exists a sharp difference between the responses of atmospheric concentrations of air pollutants and greenhouse gases to COVID-19 emission changes due to their different lifetimes. The recent road traffic emission changes under the impact of the COVID-19 pandemic have been estimated in [31] using emerging non-fuel consumption data, such as human mobility data that tech companies reported as activity data, due to the unavailability of timely fuel statistics (like how this is done in high-resolution bottom-up approaches, for example, in [32]). The use of such unconventional activity data can provide emission estimates in near-real time; however, the errors and uncertainties associated with such estimates are expected to be higher than those of the commonly used fossil fuel $\mathrm{CO}_{2}$ inventory estimates. This study highlighted the challenges in the use of limited "non-scientific" data for modeling human activities and assessing the impact on the environment. It demonstrated the importance of performing uncertainty assessments before using such data in policy applications.

The aim of this study is to apply the concept of the "center of gravity" to the spatial modeling and analysis of the spread of COVID-19 in Europe based on data on new cases and deaths. The 
peculiarities of the concept of the center of gravity and the method of physical analogies used for the construction of the approach to the spatial analysis of the prevalence of morbidity are shown. Using an approximation of the weekly data, the delays between the peaks of new cases and mortality for different countries were calculated, as well as the delays in comparison with the countries that first reached the peaks of morbidity and mortality. Similar trajectories of the center of gravity are also calculated for the administrative regions of Ukraine as an example of analysis at the national scale.

\section{Mathematical model based on the "center of gravity"}

In general, the center of gravity of a mechanical system is a point relative to which the total moment of the gravitational forces acting on the system is zero [33]. In a homogeneous gravitational field, the center of gravity always coincides with the center of mass. In non-astronomical problems, the gravitational field is usually considered constant within the object under analysis, so in practice, the center of gravity and the center of mass coincide. The same situation occurs when this concept is used by analogy in other study fields, where there is no real gravitational field and it makes no sense to talk about its homogeneity [34]. In this sense, these two terms are synonymous. In the same sense, we used the concept of the center of gravity in the current study to model the spread of COVID-19.

There are several studies in which the concept of the center of gravity is used to analyze various processes. For example, there are studies concerning the analysis of China's international economic policy of One Belt One Road (OBOR) and the global economic center of gravity [35], the analysis of the financial markets and the political center of gravity [36], the estimation of "gravity" models in international trade [37], the use of gravity models to explain trade-based money laundering worldwide in a plausible manner $[38,39]$ and the analysis of the shifting locations of the centers of gravity of four basic global indicators (the gross domestic product, carbon dioxide emissions, population and urban population) to explain the model of economic growth and its sustainability with increasing challenges related to globalization [40]. It is interesting to use the concept of the center of gravity for the analysis of air pollution and carbon dioxide emissions from fossil fuel consumption, in particular the evolution of air pollution in the Yangtze River Delta of China [41], the spatial data analysis of prefecture-scale pollutant and $\mathrm{CO}_{2}$ emissions in China [42], the analysis of global energy-related $\mathrm{CO}_{2}$ emissions [43] and the study of seasonal changes in fossil fuel $\mathrm{CO}_{2}$ emissions for the United States through employing the Vulcan version 3.0 high-resolution emission data [32]. Grether \& Mathys [44] used the concept of the center of gravity to analyze the spread of COVID-19 globally, and this approach is based on previous work [45]. In the current study, a similar approach is used for the spatial analysis of the spread of the morbidity and mortality of COVID-19 for Europe and Ukraine as a partial case.

To determine the geographical coordinates of the center of gravity for a particular analyzed parameter (new cases or fatalities) for many geographical features (countries or regions), we used the vector expression

$$
\boldsymbol{r}_{c, i}=\frac{\sum_{n=1}^{N} p_{n, i} \cdot \boldsymbol{r}_{n}}{\sum_{n=1}^{N} p_{n, i}}, \quad i=1,2, \ldots,
$$

where $\boldsymbol{r}_{c, i}$ is the radius-vector from the origin of the selected coordinate system to the desired point of the center of gravity for the $i$-th week (actually, the coordinates of this point are used to build the trajectory of the center of gravity), $p_{n, i}$ is the magnitude of the analyzed parameter (new cases or deaths) for the $i$-th week for the $n$-th geographical object, $\boldsymbol{r}_{n}$ is the radius-vector from the origin of the selected coordinate system to the center of gravity of the $n$-th geographical object, $i$ is the number of weeks covered by the study (the counting of weeks started from March 22, 2020), $n=\overline{1, N}$ is the number of countries or regions covered by the analysis and $N$ is the total number of countries/regions. It is assumed that the center of gravity for the analyzed parameter for a separate geographical object coincides with the centroid of the polygon bounded by the boundary of this object (country or region). In practice, this is equivalent to assuming that the analyzed parameter (number of new cases or 
deaths) is evenly distributed within the country/region. In each iteration of the use of formula (1), the geolocation of the center of gravity changes, which reflects the dynamics of the spread of new cases/mortality. The center of gravity is a characteristic of the analyzed system of geographical objects, so the selected coordinate system and its origin when applying formula (1) do not matter. Instead, the chosen coordinate system is important when illustrating the calculated trajectory of the center of gravity using a certain geographical projection.

\section{Trajectory of the "center of gravity" for European countries}

In Europe, the study covered 44 countries. Official data on the number of COVID-19 new cases and deaths for European countries are taken from [2]. To eliminate random jumps in the data, they were aggregated to weekly values and an appropriate geospatial database was created. The state borders of the countries in the form of vector map polygons were downloaded from [46]. Some remote marine territories (islands/archipelagos in the ocean) were not taken into account when calculating centroids corresponding to the analyzed countries, in particular, Spain (the Canary Islands and the Balearic Islands), Portugal (Azores and Madeira), Norway (the remote Arctic island of Jan Mayen, the archipelago of Svalbard, Bouvet Island in the Subantarctic and other islands), etc. These territories are sparsely populated and did not affect the overall pattern of the disease. Only the European part of the Russian Federation is considered, and statistical data for this part were calculated in proportion to the population living there $(78 \%)$. Data from Turkey are not covered by this study, as most of the country is in Asia (both population and area), and therefore the centroid of the polygon corresponding to the country's territory is also in Asia.

Using formula (1) and the assumptions described above, the geographical coordinates of the centers of gravity were calculated, and their trajectories were built for both the new reported cases of COVID-19 (Fig. 1) and the number of deaths (Fig. 2), based on weekly data for all European countries. The diameters of the circles reflecting the centers of gravity are proportional to the total number of new cases per week in 44 European countries. The southwestern beginning of the trajectory in Fig. 1 is due to the high level of coronavirus incidence in Italy and Spain during spring 2020. Then, the curve went up, which was affected by the situation in the United Kingdom. Further, the intensity of the disease in these countries decreased, but the situation in the Russian Federation began to play a significant role and, accordingly, the trajectory of the center of gravity moved in a northeastern direction. However, rather quickly (a higher density of points on the trajectory), the center of gravity returned to the territory of Switzerland and southern Germany, because in Europe, an unprecedented wave of morbidity was beginning. The amplitude of this trajectory reached $1,600 \mathrm{~km}(1,500 \mathrm{~km}$ in the horizontal direction and $500 \mathrm{~km}$ in the vertical direction). In Fig. $1 \mathrm{~b}$, the first wave of morbidity is clearly visible, while the barrier between the second and third waves is not obvious for Europe, as different countries reach the peaks in morbidity and mortality at different times.

The trajectory of the center of gravity for deaths (Fig. 2) is similar. It begins near Monaco, passes through France, Germany, Austria, Poland and Ukraine, and stays for a long time in Central Europe during the rather long second wave of the disease. A significant jump in the curve in June 2020 was caused by abnormal reporting by Spain when more deaths were reported all in one day. The amplitude of this curve in the vertical direction was about $900 \mathrm{~km}$. Since all European countries experienced waves of morbidity at different times, the curve in Fig. $2 \mathrm{~b}$ has more extremes. 


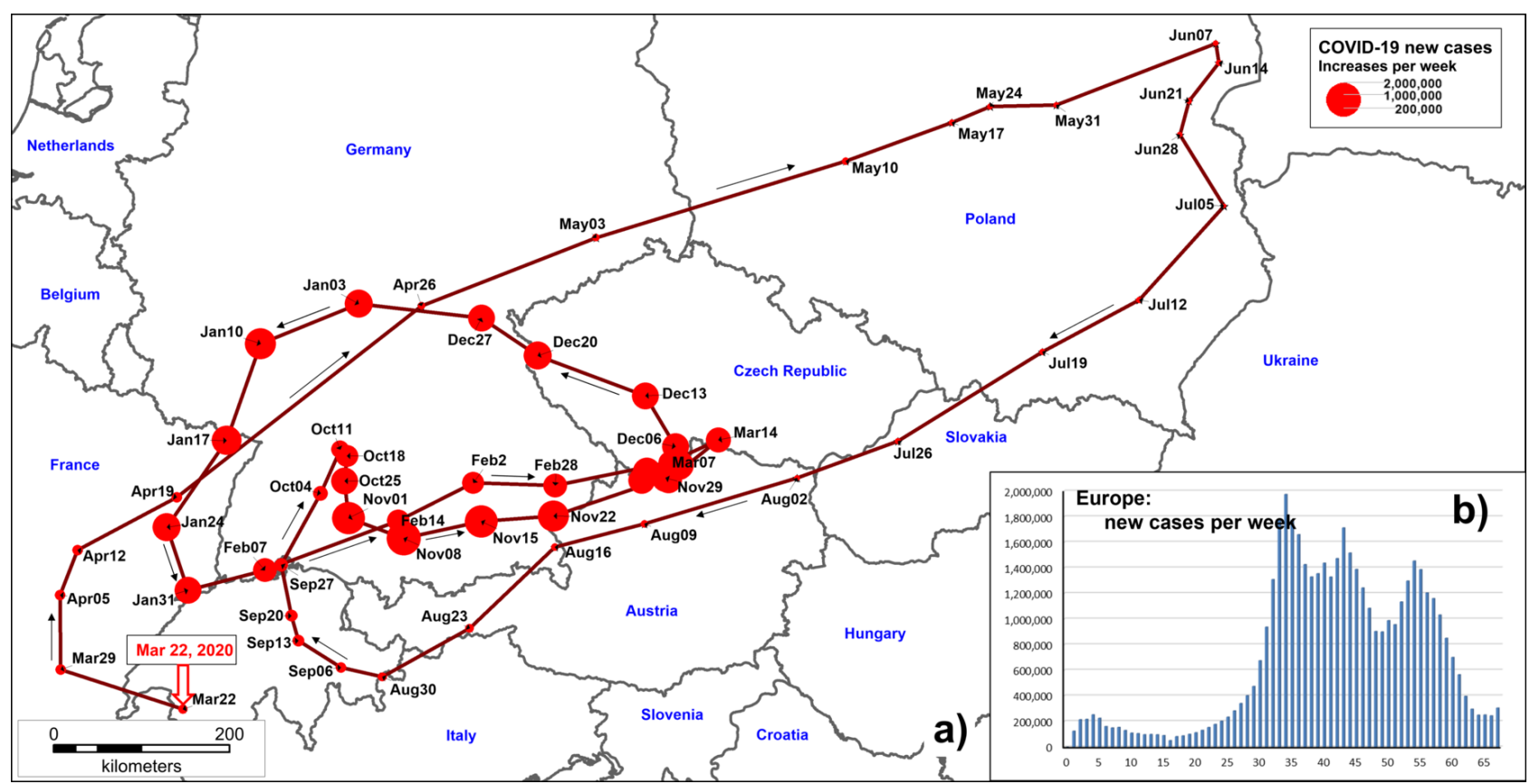

Fig. 1. The trajectory of the center of gravity for weekly new cases of COVID-19 for European countries: spread dynamics (a); peaks of incidence (b) (on the abscissa axis, the number of weeks is indicated, starting from March 22, 2020, and on the ordinate axis, the total number of new cases in European countries is presented).

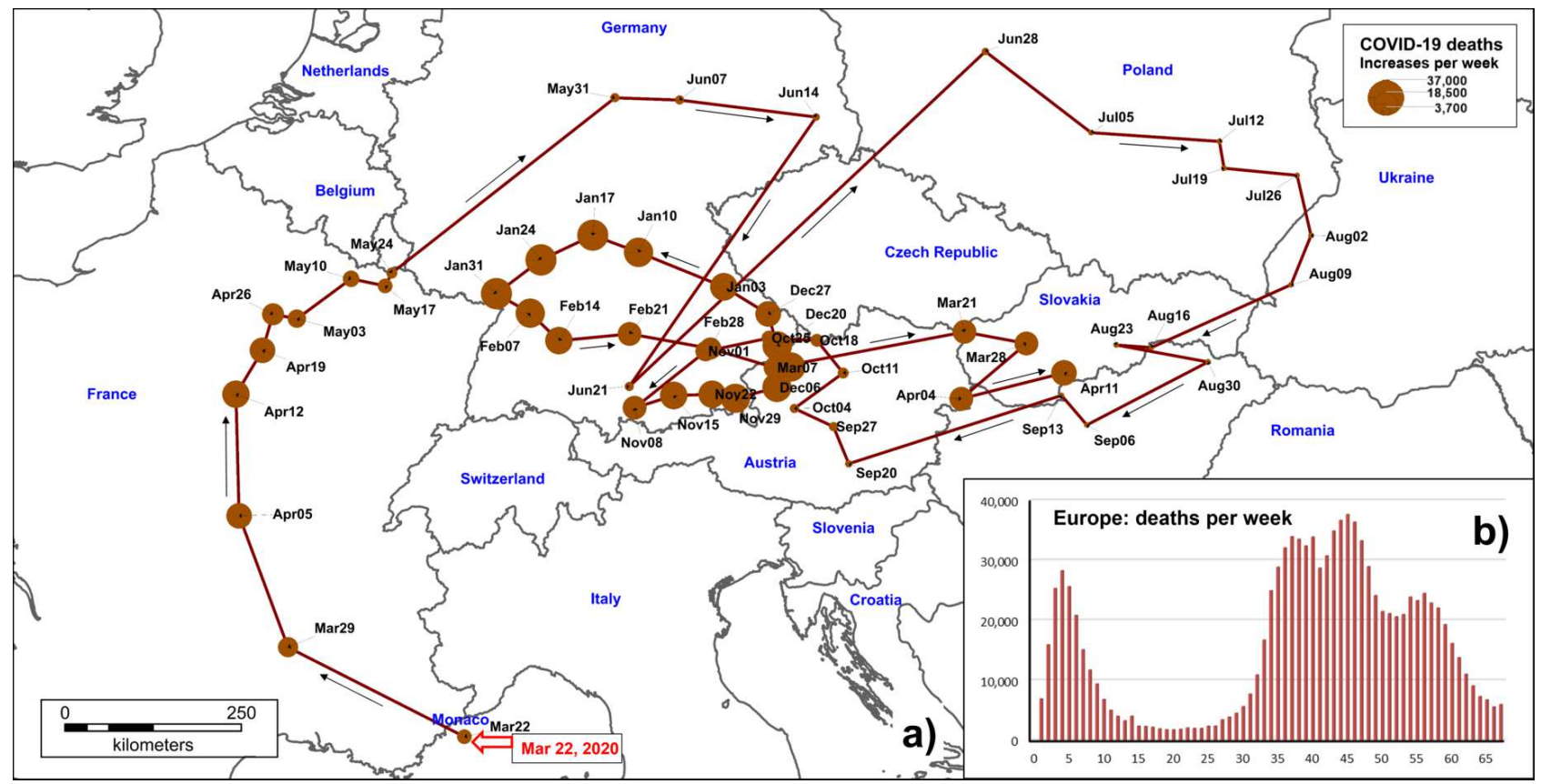

Fig. 2. The trajectory of the center of gravity for weekly deaths from COVID-19 for European countries (a) and mortality peaks (b) (the abscissa axis shows the number of weeks starting from March 22, 2020, and the ordinate axis shows the total number of deaths in Europe). 


\section{Trajectory of the "center of gravity": Ukraine case study}

Similar trajectories of the centers of gravity were calculated for the regions of Ukraine regarding new cases of COVID-19 (Fig. 3) and COVID-19 deaths (Fig. 4).

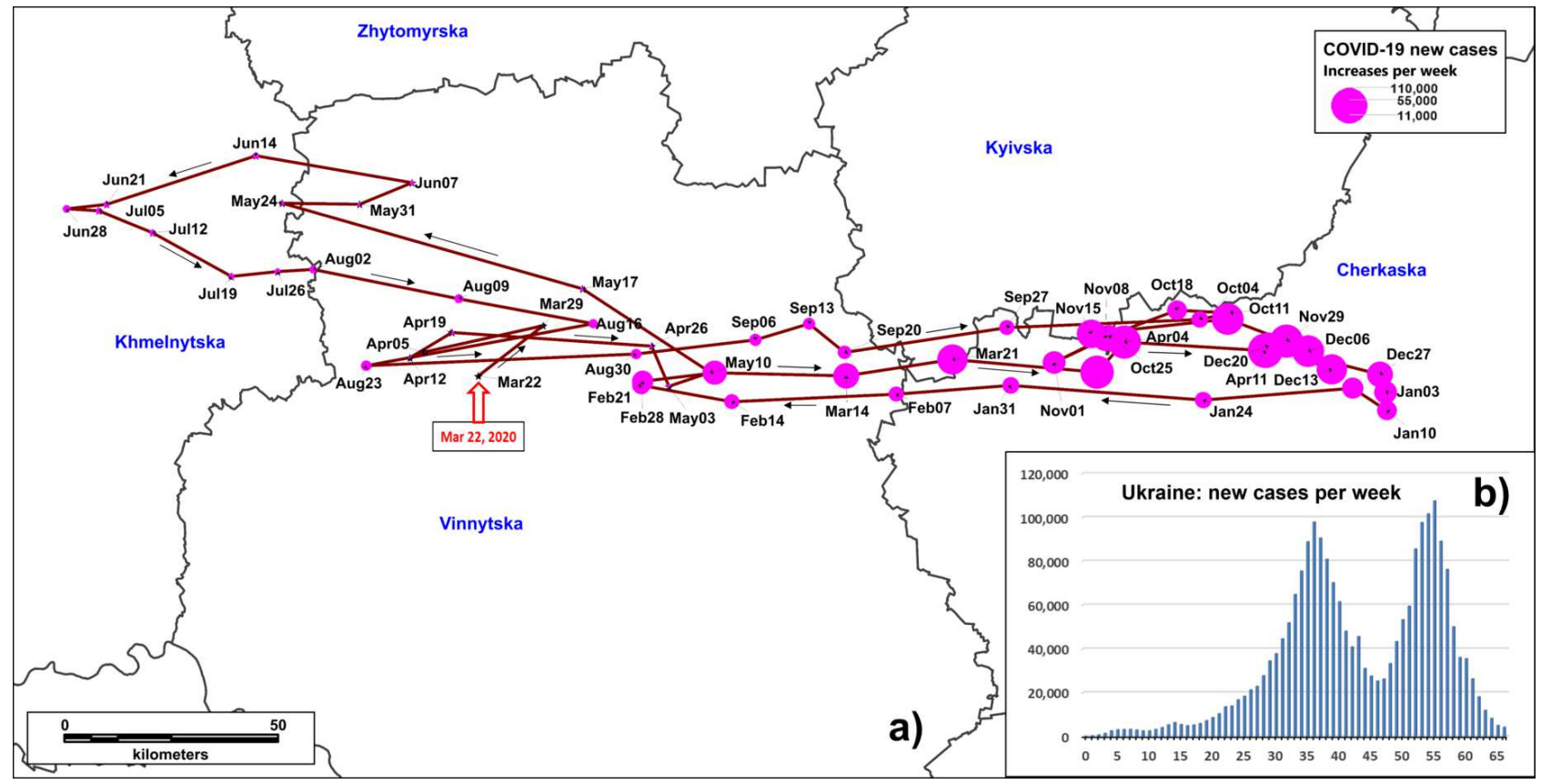

Fig. 3. The trajectory of the center of gravity for weekly new cases of COVID-19 in the regions of Ukraine: dynamics of spread (a) and peaks (b) (week numbers on the abscissa axis, and number of new cases on the ordinate axis).

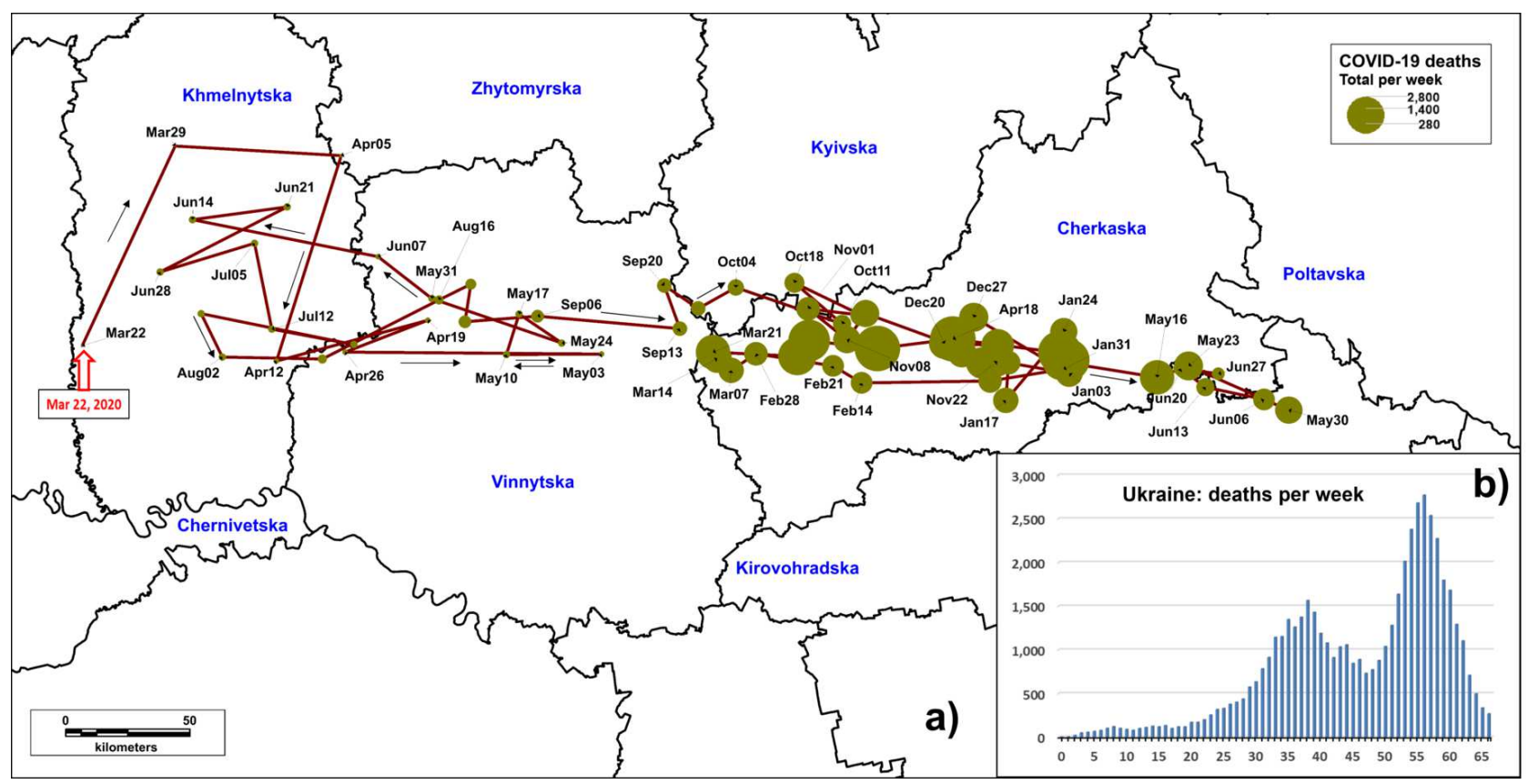

Fig. 4. The trajectory of the center of gravity for weekly deaths from COVID-19 in Ukraine (a) and mortality peaks (b) (week numbers on the abscissa axis, and total number of deaths in the country during each week on the ordinate axis).

Due to the lack of relevant data, the situation in the Autonomous Republic of Crimea and the uncontrolled territories of Luhansk and Donetsk is not considered. The trajectory for new cases (Fig. 3) illustrates well the predominance of the western or eastern regions of Ukraine during certain periods 
of the pandemic. Moreover, the western regions were prominent during the relatively small first wave, and the eastern regions during the catastrophically high waves, when the number of new cases per week was over 100,000. Then, the center of gravity moved even further west, and from June 2020, it began to move rapidly in an easterly direction. The amplitude of the trajectory in the horizontal direction was more than $300 \mathrm{~km}$, and in the vertical direction, it was insignificant.

The trajectory of the center of gravity of deaths has a similar appearance (Fig. 4). From the beginning of the pandemic until September 2020, the trajectory of the center of gravity was in the territory of Western Ukraine (the Khmelnytsky and Vinnytsia regions). During the periods of the two largest peaks in mortality (1,566 and 2,772 deaths per week, respectively), the center of gravity was in the west of the Cherkasy region, and after May 2021, it moved to the east (to the border between the Cherkasy and Kirovohrad regions). The amplitude of the trajectory in the horizontal direction was quite large, about $500 \mathrm{~km}$, which indicates a significant predominance of the western, central or eastern regions in different periods of the pandemic. The amplitude in the vertical direction was less than $50 \mathrm{~km}$ (except for the first few weeks, when the number of deaths was not high).

\section{Delays between new cases and deaths}

The waves of the COVID-19 pandemic and the peaks of new cases/deaths for Europe as a whole are not as obvious (Fig. 1 and Fig. 2) as they are for most countries considered on their own (Fig. 5). This was significantly influenced by different rates of disease spread, different restrictive measures in different countries and so on. The first waves of the pandemic began in Italy and Spain, then spread to France, the United Kingdom and Germany (Fig. 5). In Poland and Ukraine, on the other hand, this wave was not so high. Therefore, the delays between the peaks of new cases and the peaks of deaths for different countries and different waves of the pandemic are very diverse, as were the delays compared to Italy, which was the first country in Europe to spread COVID-19 (Table1). Such delays were calculated from the local approximation of the curves of new cases and deaths (Fig. 5) by using second-order interpolation polynomials and determining the distance between their maxima (Fig. 6).

Italy. This country was the first to experience the first peak of the pandemic; the calculated delay between the maximums of new cases and mortality was small (4 days), and for the second peak, it was near 2.5 weeks. That is why, in Table 1, the delays of the peaks compared to the peak in Italy are presented.

Spain. During the first wave of the pandemic, Spain was also one of the first countries to reach the peak of morbidity/mortality (with a delay of 2 weeks after the Italian peak). However, the second and third waves lasted a long time and quite high peaks were reached from January-February 2021 (the delay between the peaks of new cases and mortality was already 2.3 weeks).

France. This country is a leader in Europe in terms of the total number of people infected during the pandemic. There is some ambiguity about the first peak at the beginning of the pandemic, as reporting was not yet stable, and therefore the above approach to calculating the delay cannot be applied to the available data. During the first wave, the peak of new cases lagged behind the Italian peak by 2.4 weeks (mortality during this peak was the highest), but the second peak was ahead of the Italian peak. The peaks of new cases/deaths were quite high and the delay between them was 1.9 weeks.

United Kingdom. The first wave lasted a long time, almost 5 weeks (a delay of 3.4 weeks compared to the Italian peak), and there was a very high mortality rate. The second peak of new cases began almost simultaneously with France's second peak, and there was a very high third peak. In terms of mortality, the second peak passed to the third, even higher and more acute peak (the delay of the mortality peak was 2.3 weeks).

Germany. After the first peak, there was a very long plateau (the delay of the peak of deaths was 2.4 weeks). The second peak was quite wide and very late compared to other countries. Mortality was low, and the delay was 3.6 weeks. 


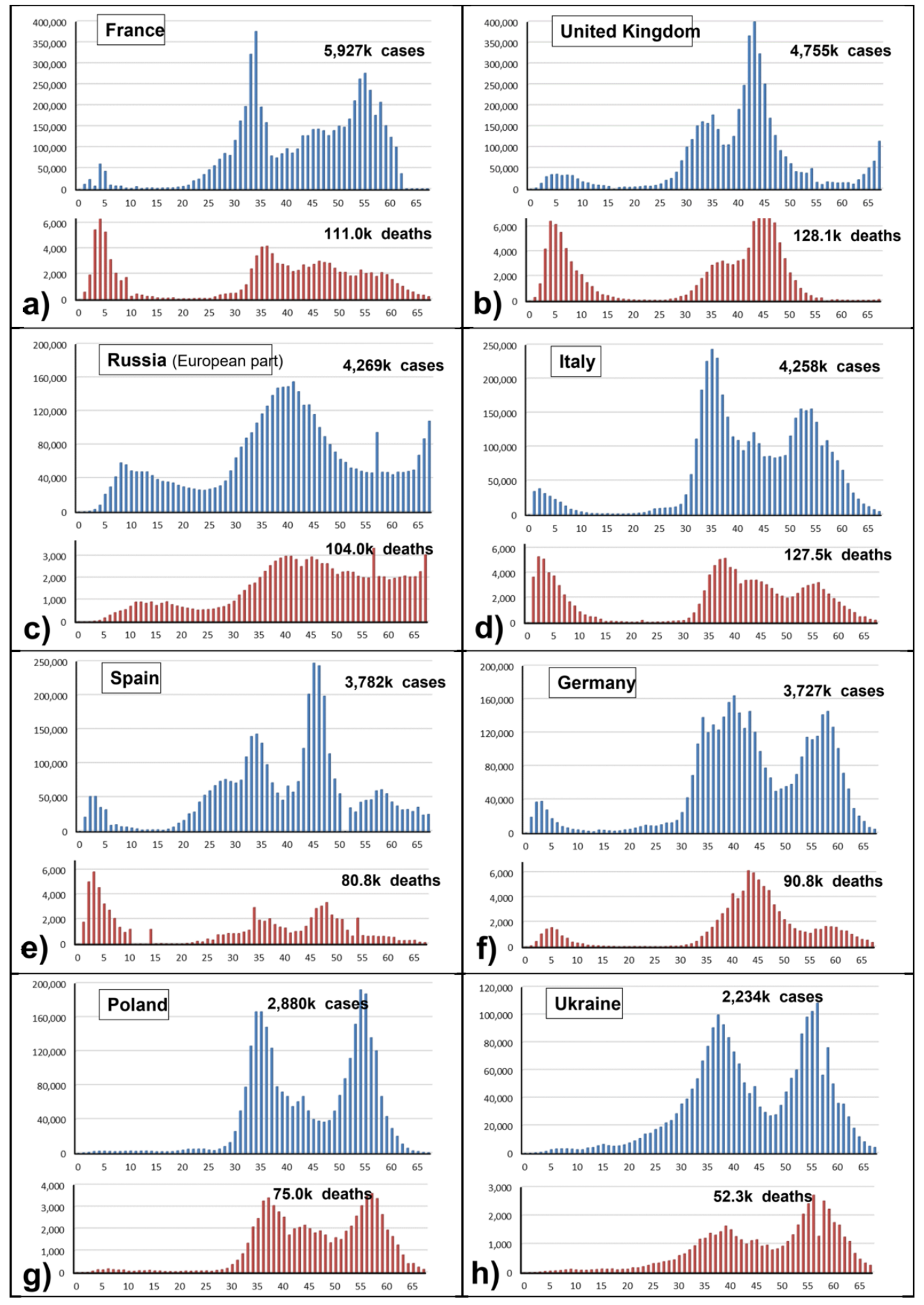

Fig. 5. Number of new COVID-19 cases (upper plots) and deaths (lower plots) per week in the European countries most affected by the pandemic. The week numbers beginning from March 22, 2020, are indicated on the abscissa axis. On each graph, the total number of COVID-19 cases/deaths for each country is shown. 
Table 1. Delays between peaks of new cases and deaths for eight countries with the highest numbers of people infected by COVID-19. Delays have been calculated based on a comparison of the maxima of corresponding approximation curves.

\begin{tabular}{|l|c|c|c|}
\hline \multirow{2}{*}{ Country } & $\begin{array}{c}\text { Delay compared to } \\
\text { the 1st peak in Italy, } \\
\text { weeks }\end{array}$ & $\begin{array}{c}\text { Delay of deaths peak compared to new cases peak } \\
\text { The 1st pandemic wave }\end{array}$ & The 2nd pandemic wave \\
\hline Italy & - & 0.5 & 2.5 \\
\hline Spain & 2.0 & 0.9 & 2.3 \\
\hline Germany & 2.6 & 2.4 & 3.6 \\
\hline United Kingdom & 3.3 & 1.1 & 2.3 \\
\hline France & 4.3 & - & 1.9 \\
\hline Poland & 4.6 & 1.5 & 2.8 \\
\hline Ukraine & 7.6 & 1.4 & 2.0 \\
\hline Russian Federation & 8.4 & 3.2 & 1.5 \\
\hline Europe (total) & 3.8 & 0.2 & 3.3 \\
\hline
\end{tabular}

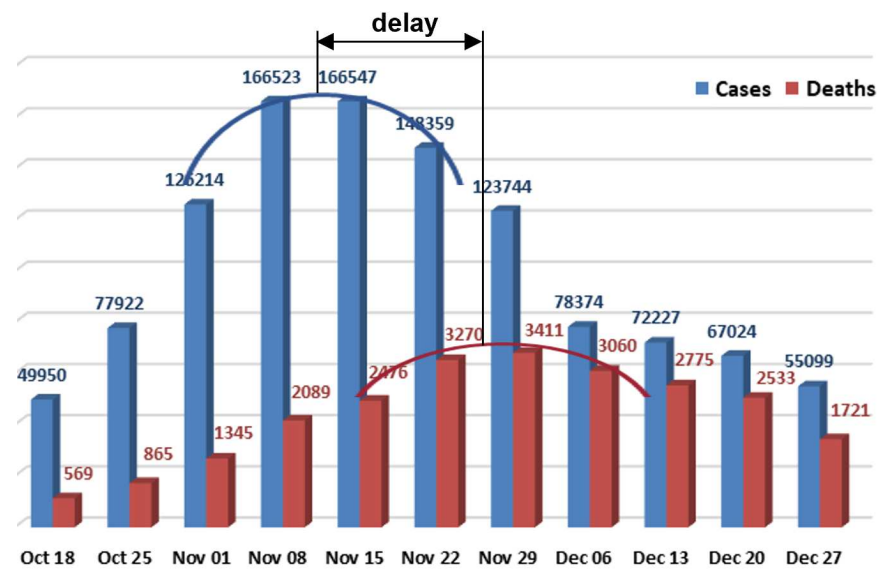

Fig. 6. Illustration of the procedure for calculating the delay between peaks of new cases and peaks of deaths by using interpolation polynomials and finding the distance between their maxima (Poland's data is an example). The weekly numbers of new cases and deaths are indicated by the corresponding columns (the scales of these two values in the vertical direction are not the same).
Russian Federation. The peaks were very smooth, especially for new cases, as shown by the coefficients of the second derivative of the interpolation polynomial (the second derivative of the number of cases). Accordingly, the peak of deaths lasted a very long time. There was a long delay (3.0 weeks), but it is difficult to recognize it because the curves are smooth. The first peak lagged behind the Italian by as much as 6.5 weeks, which significantly pulled the center of gravity (Fig. 2) to the northeast.

Poland. Compared to other EU countries, Poland passed the first wave of the pandemic relatively easily. The first peak was not pronounced, and until September 2020, the rate of new cases remained almost at the same level (the mortality delay was 1.5 weeks). During the second and third waves, there were 2 peaks with mortality delays of 2.8 and 2.5 weeks, respectively.

Ukraine. At the beginning of the pandemic, there were 2 small highs. Compared to other countries, it is not even possible to say whether it was 1 or 2 peaks. During the second and third waves, there were 2 high peaks of morbidity and mortality; the delay during the first peak was 2.0 weeks.

Europe. In total, for all European countries, the first peaks of new cases and deaths almost coincided (Table 1 ), and the delay was only 2 days because this was only the beginning of the pandemic and different European countries approached it very unevenly. On the other hand, for the second peak, the delay between the maximum number of new cases and the maximum mortality was already 3.3 weeks.

\section{Conclusions}

The obtained results clearly illustrate the use of the concept of the center of gravity for the spatial analysis of the spread of COVID-19, in particular the registered new cases and fatalities. These results show which countries or regions are most influential in the movement of pan-European or national 
centers of gravity for a given parameter. The amplitude of the trajectory of the center of gravity was more than $1,600 \mathrm{~km}$, and the amplitude in the horizontal direction was 3 times greater than the amplitude in the vertical direction. In general, the pandemic situation in European countries was very diverse (Fig. 7). The highest numbers of reported cases of COVID-19 from the beginning of the pandemic to June 2021 were in France ( 5.9 million), the United Kingdom ( 4.8 million) and the European part of the Russian Federation ( 4.3 million). The largest percentages of the population infected occurred in smaller countries such as Andorra (18.0\%), San Marino (16.0\%), Czechia (16.3\%) and Montenegro (16.1\%), while the lowest percentages of the population infected occurred in Iceland $(2.2 \%)$ and Finland (1.8\%). The death rate was highest in Bosnia and Herzegovina (4.6\%), Bulgaria $(4.3 \%)$ and Hungary $(3.7 \%)$, and it was lowest in Norway $(0.61 \%)$ and Iceland $(0.45 \%)$.

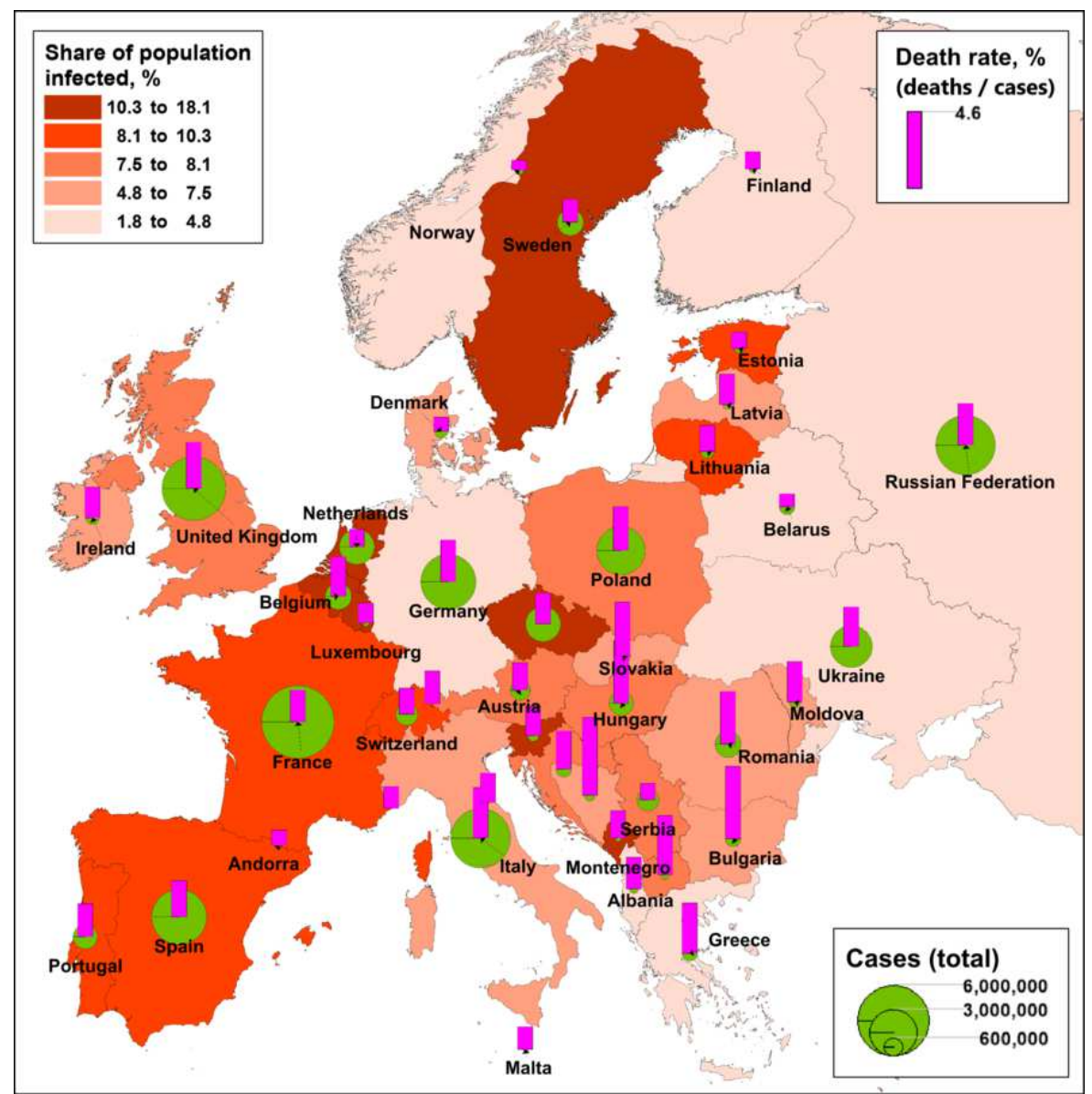

Fig. 7. Summary data on reported cases of COVID-19 in European countries: proportion of infected population, death rate and total number of reported cases during a pandemic.

The approximation of data on new cases and deaths made it possible to determine the delay between the peaks of these two parameters. In particular, in Europe during the second wave of the pandemic, the highest peak of new cases (1,943,538 cases) occurred during the week ending on November 8, 2020. It was followed by a peak of mortality (33,233 cases) with a delay of 3.3 weeks (approximately 23 days). Europe experienced the highest mortality rate during the third wave of the pandemic $(36,780$ cases during the week ending on January 24, 2021), although a slightly smaller peak preceded this in new cases than during the second wave. The delay between the peaks of new cases and mortality was only 1.9 weeks (13 days).

The results of the analysis also showed the delay in the countries' peaks of new cases of COVID-19 and deaths with respect to Italy, which was the first to survive the first wave of the pandemic. In general, country-specific data vary widely and show how prepared countries were for a pandemic. 
[1] Worldometer: COVID-19 coronavirus pandemic, 2021. https://www . worldometers .info/coronavirus/.

[2] Azure Open Datasets Catalog: COVID-19 Data Lake, 2021.

https://azure.microsoft.com/en-us/services/open-datasets/catalog/covid-19-data-lake/.

[3] Zhang X., Ma R., Wang L. Predicting turning point, duration and attack rate of COVID-19 outbreaks in major Western countries. Chaos, Solitons \& Fractals. 135, 109829 (2020).

[4] Zivkovic M., Bacanin N., Venkatachalam K., Nayyar A., Djordjevic A., Strumberger I., Al-Turjman F. COVID-19 cases prediction by using hybrid machine learning and beetle antennae search approach. Sustainable Cities and Society. 66, 102669 (2021).

[5] Kim J., Kwon O. A model for rapid selection and COVID-19 prediction with dynamic and imbalanced data. Sustainability. 13 (6), 3099 (2021).

[6] Vyklyuk Y., Manylich M., Škoda M., Radovanović M. M., Petrović M. D. Modeling and analysis of different scenarios for the spread of COVID-19 by using the modified multi-agent systems - Evidence from the selected countries. Results in Physics. 20, 103662 (2021).

[7] Tuli S., Tuli S., Tuli R., Gill S. S. Predicting the growth and trend of COVID-19 pandemic using machine learning and cloud computing. Internet of Things. 11, 100222 (2020).

[8] Yakovyna V., Shakhovska N. Modelling and predicting the spread of COVID-19 cases depending on restriction policy based on mined recommendation rules. Mathematical Biosciences and Engineering. 18 (3), 2789-2812 (2021).

[9] Basu S., Campbell R. H. Going by the numbers: Learning and modeling COVID-19 disease dynamics. Chaos, Solitons \& Fractals. 138, 110140 (2020).

[10] Siddique A., Shahzad A., Lawler J., Mahmoud K. A., Lee D. S., Ali N., Bilal M., Rasool K. Unprecedented environmental and energy impacts and challenges of COVID-19 pandemic. Environmental Research. 193, 110443 (2021).

[11] Kim M. H., Kim J. H., Lee K., Gim G.-Y. The prediction of COVID-19 using LSTM algorithms. International Journal of Networked and Distributed Computing. 9 (1), 19-24 (2021).

[12] Morgan A. K., Awafo B. A., Quartey T. The effects of COVID-19 on global economic output and sustainability: evidence from around the world and lessons for redress. Sustainability: Science, Practice and Policy. 17 (1), 77-81 (2021).

[13] Kano T., Yasui K., Mikami T., Asally M., Ishiguro A. An agent-based model of the interrelation between the COVID-19 outbreak and economic activities. Proceedings of the Royal Society A: Mathematical, Physical and Engineering Sciences. 477 (2245), 20200604 (2021).

[14] Jiang P., Van Fan Y., Klemeš J. J. Impacts of COVID-19 on energy demand and consumption: Challenges, lessons and emerging opportunities. Applied Energy. 285, 116441 (2021).

[15] Ciais P., Bréon F.-M., Dellaert S., Wang Y., Tanaka K., Gurriaran L., Franзoise Y., Davis S., Hong C., Penuelas J., Janssens I., Obersteiner M., Deng Z., Liu Z. Impact of lockdowns and winter temperatures on natural gas consumption in Europe. Earth's Future. 10, e2021EF002250 (2021).

[16] Werth A., Gravino P., Prevedello G. Impact analysis of COVID-19 responses on energy grid dynamics in Europe. Applied Energy. 281, 116045 (2021).

[17] Straka W., Kondragunta S., Wei Z., Zhang H., Miller S. D., Watts A. Examining the economic and environmental impacts of COVID-19 using Earth observation data. Remote Sensing. 13 (1), 5 (2021).

[18] Levelt P. F., Zweers D. C. S., Aben I., Bauwens M., Borsdorff T., De Smedt I., Eskes H. J., Lerot C., Loyola D. G., Romahn F., Stavrakou T., Theys N., Van Roozendael M., Veefkind J. P., Verhoelst T. Air quality impacts of COVID-19 lockdown measures detected from space using high spatial resolution observations of multiple trace gases from Sentinel-5P/TROPOMI. Atmospheric Chemistry and Physics Discussions. 2021, 1-53 (2021).

[19] Ghosh T., Elvidge C. D., Hsu F.-C., Zhizhin M., Bazilian M. The dimming of lights in India during the COVID-19 pandemic. Remote Sensing. 12 (20), 3289 (2020).

[20] Yusup Y., Ramli N. K., Kayode J. S., Yin C. S., Hisham S., Isa H. M., Ahmad M. I. Atmospheric carbon dioxide and electricity production due to lockdown. Sustainability. 12 (22), 9397 (2020). 
[21] Le Quéré C., Jackson R. B., Jones M. W., Smith A. J. P., Abernethy S., Andrew R. M., De-Gol A. J., Willis D. R., Shan Y., Canadell J. G., Friedlingstein P., Creutzig F., Peters G. P. Temporary reduction in daily global $\mathrm{CO}_{2}$ emissions during the COVID-19 forced confinement. Nature Climate Change. 10, 647-653 (2020).

[22] Liu Z., Ciais P., Deng Z., Davis S. J., Zheng B., Wang Y., Cui D., Zhu B., Dou X., Ke P., Sun T., Guo R., Zhong H., Boucher O., Bréon F.-M., Lu C., Guo R., Xue J., Boucher E., Tanaka K., Chevallier F. Carbon Monitor, a near-realtime daily dataset of global $\mathrm{CO}_{2}$ emission from fossil fuel and cement production. Scientific Data. 7, 392 (2020).

[23] Liu Z., Ciais P., Deng Z., Lei R., Davis S. J., Feng S., Zheng B., Cui D., Dou X., Zhu B., Guo R., Ke P., Sun T., Lu C., He P., Wang Y., Yue X., Wang Y., Lei Y., Zhou H., Cai Z., Wu Y., Guo R., Han T., Xue J., Boucher O., Boucher E., Chevallier F., Tanaka K., Wei Y., Zhong H., Kang C., Zhang N., Chen B., Xi F., Liu M., Bréon F.-M., Lu Y., Zhang Q., Guan D., Gong P., Kammen D. M., He K., Schellnhuber H.J. Nearreal-time monitoring of global $\mathrm{CO}_{2}$ emissions reveals the effects of the COVID-19 pandemic. Nature Communications. 11, 5172 (2020).

[24] Liu Z., Deng Z., Ciais P., Tan J., Zhu B., Davis S. J, Andrew R., Boucher O., Arous S. B., Canadell P., Dou X., Friedlingstein P., Gentine P., Guo R., Hong C., Jackson R. B., Kammen D. M., Ke P., Le Quéré C., Monica C., Janssens-Maenhout G., Peters G., Tanaka K., Wang Y., Zheng B., Zhong H., Sun T., Schellnhuber H. J. Global daily $\mathrm{CO}_{2}$ emissions for the year 2020. Preprint arXiv:2103.02526 (2021).

[25] Liu Z., Zhu B., Ciais P., Davis S. J., Lu C., Zhong H., Ke P., Cui Y., Deng Z., Cui D., Sun T., Dou X., Tan J., Guo R., Zheng B., Tanaka K., Zhao W., Gentine P. De-carbonization of global energy use during the COVID-19 pandemic. Preprint arXiv:2102.03240 (2021).

[26] Zeng N., Han P., Liu D., Liu Z., Oda T., Martin C., Liu Z., Yao B., Sun W., Wang P., Cai Q., Dickerson R., Maksyutov S. Global to local impacts on atmospheric $\mathrm{CO}_{2}$ caused by COVID-19 lockdown. Preprint arXiv:2010.13025 (2020).

[27] Weir B., Crisp D., O’Dell C. W., Basu S., Chatterjee A., Oda T., Ott L. E., Pawson S., Poulter B., Zhang Z., Ciais P., Davis S. J., Liu Z. Regional impacts of COVID-19 on carbon dioxide detected worldwide from space. Science Advances. 7 (45), eabf9415 (2020).

[28] Wang Y., Deng Z., Ciais P., Liu Z., Davis S. J., Gentine P., Lauvaux T., Ge Q. Transportation $\mathrm{CO}_{2}$ emissions stayed high despite recurrent COVID outbreaks. Scientific Data. 7, 168 (2020).

[29] Han P., Cai Q., Oda T., Zeng N., Shan Y., Lin X., Liu D. Assessing the recent impact of COVID-19 on carbon emissions from China using domestic economic data. Science of The Total Environment. 750, 141688 (2021).

[30] Laughner J. L., Neu J. L., Schimel D., Wennberg P. O., Barsanti K., Bowman K., Chatterjee A., Croes B., Fitzmaurice H., Henze D., Kim J., Kort E. A., Liu Z., Miyazaki K., Turner A. J., Anenberg S., Avise J., Cao H., Crisp D., de Gouw J., Eldering A., Fyfe J. C., Goldberg D. L., Gurney K. R., Hasheminassab S., Hopkins F., Ivey C. E., Jones D. B. A., Lovenduski N. S., Martin R. V., McKinley G. A., Ott L., Poulter B., Ru M., Sander S. P., Swart N., Yung Y. L., Zeng Z.-C. The 2020 COVID-19 pandemic and atmospheric composition: back to the future. Earth and Space Science Open Archive. 11 (2021).

[31] Oda T., Haga C., Hosomi K., Matsui T., Bun R. Errors and uncertainties associated with the use of unconventional activity data for estimating $\mathrm{CO}_{2}$ emissions. Environmental Research Letters. 16 (8), 084058 (2021).

[32] Gurney K. R., Liang J., Patarasuk R., Song Y., Huang J., Roest G. The Vulcan version 3.0 high-resolution fossil fuel $\mathrm{CO}_{2}$ emissions for the United States. Journal of Geophysical Research: Atmospheres. 125 (19), e2020JD032974 (2020).

[33] Asimov I. Understanding Physics. Buccaneer Books, New York (1988).

[34] Levi M. The Mathematical Mechanic: Using Physical Reasoning to Solve Problems. Princeton University Press (2012).

[35] Chohan U. M. The political economy of OBOR and the global economic center of gravity. In: The Belt and Road Initiative, Chaisse J. and Górski J., eds. Brill \& Nijhoff. 59-82 (2018).

[36] Roe M. J., Coan T. G. Financial markets and the political center of gravity. Journal of Law, Finance, and Accounting. 2 (1), 125-171 (2017). 
[37] Baltagi B. H., Egger P. H., Erhardt K. The estimation of gravity models in international trade. In: The Econometrics of Multi-Dimensional Panels, Matyas L., ed. 323-348 (2017).

[38] Ferwerda J., Kattenberg M., Chang H.-H., Unger B., Groot L., Bikker J. A. Gravity models of trade-based money laundering. Applied Economics. 45 (22), 3170-3182 (2013).

[39] Walker J., Unger B. Measuring global money laundering: "The Walker gravity model". Review of Law and Economics. 5 (2), 821-853 (2009).

[40] Balsa-Barreiro J., Li Y., Morales A., Pentland A. Globalization and the shifting centers of gravity of world's human dynamics: Implications for sustainability. Journal of Cleaner Production. 239, 117923 (2019).

[41] Li H., Song Y., Zhang M. Study on the gravity center evolution of air pollution in Yangtze river delta of China. Natural Hazards. 90, 1447-1459 (2018).

[42] Chen J., Xu C., Li K., Song M. A gravity model and exploratory spatial data analysis of prefecture-scale pollutant and $\mathrm{CO}_{2}$ emissions in China. Ecological Indicators. 90, 554-563 (2018).

[43] Song Y., Zhang M. Study on the gravity movement and decoupling state of global energy-related $\mathrm{CO}_{2}$ emissions. Journal of Environmental Management. 245, 302-310 (2019).

[44] Grether J.-M., Mathys N. A. The Coronavirus Center of Gravity (CCG), 2021. https://ferdi.fr/en/publications/the-coronavirus-center-of-gravity-ccg.

[45] Grether J.-M., Lutzelschwab C., Mathys N. A. L'essor et le déclin de l'Occident: une perspective géographique. Revie D'Économie du Développement. 20 (2), 31-56 (2012).

[46] DIVA-GIS: Free Spatial Data (2021). http://www.diva-gis.org/gdata.

\title{
Просторовий аналіз поширення COVID-19 у Європі з використанням поняття "центр тяжіння"
}

\author{
Яворська O. ${ }^{1}$, Бунь P. ${ }^{1,2}$ \\ ${ }^{1}$ Національний університет “Львівська політехніка", \\ ${ }^{2}$ Університет WSB, Домброва Гурніча, Польща
}

Глобальна пандемія COVID-19 зачепила усі країни і перетворилася у справжній виклик людству. Вчені інтенсивно досліджують специфіку хвороби, викликаної цим вірусом, та вплив обмежувальних заходів на економіку, довкілля та інші аспекти життєдіяльності. У статті представлено підхід до просторового моделювання та аналізу процесу поширення COVID-19 з використанням поняття "центр тяжіння". На основі щотижневих даних про нові випадки та смерті від цієї недуги в усіх країнах Європи, обчислено траєкторії переміщення цього центру тяжіння впродовж пандемії. Ці дві траєкторії відображають домінуючу роль певних країн чи регіонів Європи під час різних етапів пандемії. Показано, що амплітуда переміщення центру тяжіння у напрямку довготи була досить великою (біля 1500 км) у порівнянні з амплітудою переміщення у широтному напрямку (500 км). Використовуючи апроксимацію щотижневих даних, обчислено затримки між піками нових випадків та смертності для різних країн, а також показано затримки у порівнянні з країнами, які першими досягнули піків захворювання та смертності. Траєкторії переміщення центру тяжіння обчислено також для областей України, як приклад аналізу на національному рівні. Наведені результати дають можливість зрозуміти просторову специфіку поширення COVID-19 на європейському континенті та роль окремих країн у цих складних процесах.

Ключові слова: просторове моделювання, поширення COVID-19, иентр тяжіння, траєкторія центру тяжіння, геоінформачійний підхід. 